\title{
The effect of computer-assisted instruction on students' achievement in science education
}

\author{
Renan Şeker \\ Necmettin Erbakan University, Konya, Turkey, rseker@konya.edu.tr \\ Tezcan Kartal \\ Ahi Evran University, Kırşehir, Turkey, tkartal@ahievran.edu.tr
}

\begin{abstract}
In this study, the effect of traditional and computer-assisted instructon (CAI) methods on 7th grade middle school students' achievement in the topic of "Journey to the Interior Structure of the Matter" was examined. Experimental design with pre-test and post-test control group was used. The experimental and control group students were taught for 8 weeks. Researchers used CAI (Adobe Flash, Microsoft Office) in the experimental group and traditional learning methods in the control group. The experimental group $(\mathrm{N}=23)$ and the control group $(\mathrm{N}=23)$ were selected via simple random sampling. "Journey to the Internal Structure of the Matter Success Test" developed by the researchers was used to collect data. SPSS program was used for analysis of research data. In the interpretation of the data, descriptive analyses and t-test were used. Cohen d, also calculated the effect size. Results show that the success of the students in both traditional learning and CAI methods has increased significantly.
\end{abstract}

Keywords Science Education, Computer-Assisted Instruction, Traditional Learning

\section{Fen eğitiminde bilgisayar destekli öğretimin öğrenci başarısına etkisi}

ÖZ Bu çalışmada ortaokul 7. sınıf öğrencilerinin "Maddenin İç Yapısına Yolculuk” ünitesini öğrenmelerinde geleneksel ve bilgisayar destekli öğrenme (BDÖ) yöntemlerinin öğrenci başarısı üzerindeki etkisi incelenmiştir. Araştırmada, iki faktörlü desen olarak tanımlanan ön test-son test kontrol gruplu deneysel desen kullanılmıştır. Deney ve kontrol grubu öğrencilerine 8 hafta boyunca araştırmacılar tarafindan öğretim gerçekleştirilmiştir. Araştırmacılar deney grubunda BDÖ (Adobe Flash, Microsoft Office), kontrol grubunda ise geleneksel öğrenme yöntemlerini kullanmışlardır. Araştırma Konya İli, Selçuklu ilçesinde bulunan bir devlet okulunda yürütülmüştür. Çalışmanın deney $(\mathrm{N}=23)$ ve kontrol $(\mathrm{N}=23)$ grupları basit seçkisiz örnekleme yöntemi kapsamında belirlenmiştir. Ölçme aracı olarak araştırmacılar tarafından geliştirilen "Maddenin Iç Yapısına Yolculuk Başarı Testi" uygulanmıştır. Araştırma verileri SPSS programı ile analiz edilmiştir. Verilerin yorumlanmasında ise frekans, yüzde, aritmetik ortalama, standart sapma hesaplanmış ve ikili değişkenler için t-testi kullanılmıştır. Ayrıca, etki büyüklüğü indekslerinden Cohen d hesaplanmıştır. Araştırma sonuçlarına göre, geleneksel öğrenme ile BDÖ yöntemlerinin her ikisinde de öğrenci başarısının anlamlı olarak arttığı görülmüştür.

Anahtar 


\section{EXTENDED SUMMARY IN ENGLISH}

Educational technology tools such as computers, data acquisition and analysis software, digital microscopes, hypermedia/multimedia, student response systems, and interactive whiteboards can help students understand and research the nature of science and acquire scientific knowledge. When educational technology tools are appropriately and effectively used in science classes, students actively reach knowledge and students' thinking and problem-solving skills develop (Bybee, Powell, \& Trowbridge 2008). Along with the widespread use of computers that provide a different dimension to information access and information provision, various technology-based instructional environments have also begun to be used in the teaching processes. One of them is "Computer Assisted Instruction (CAI)", which is a teaching method that is used as a medium where the computer is used as a learning tool, which can be used according to the learning speed of the student and the learning process is integrated with the computer technology which strengthens the teaching process and student motivation (Sahin, \& Yıldırım 1999; Uşun, 2000).

The use of computers makes science courses particularly realistic and understandable. Concepts that are abstract and difficult to perceive can be concretized by computers. This facilitates meaningful learning. Morse (1991) stated that the importance of computers in a science class cannot be limited by the qualifications of the CAL. On the contrary, the use of computers allows the teacher to add a new dimension to his/her strategy repertoire, which will improve full learning. Computer animation is the most visual process in teaching with computer support. Computer animation is a series of images and a quick display of the image on the screen. Animation helps in providing visual, quick and concise learning by providing it in the best possible way. Presenting them in a humorous way by caricaturizing them can increase the desire to transform the educational process into a cute one by getting out of boredom. All these features are presented in color and sound with simple graphic symbols that symbolize the nature of movement and movement (Çakır 1999). In this study, by providing a rich learning environment with picture, sound and image effects, the preparation of multimedia materials and their transfer to the classroom environment have been examined to determine the student's success and the permanence of the learners.

In the study, a real experimental design with pre-test and post-test control group, which is defined as two-factors pattern, is used. The effects of traditional learning and CAI methods in the learning of 7th grade middle school students "Journey to the Interior of Matter" were examined in terms of student academic achievement. Since the effect of independent variables (traditional and CAI methods) on a dependent variable (student academic achievement) was examined, it was decided to use experimental design.

The experimental group $(\mathrm{N}=23)$ and the control group $(\mathrm{N}=23)$ were determined by simple random sampling method. In this context, experimental group $(\mathrm{N}=23)$ and control group $(\mathrm{N}=23)$ were included in the study group from a primary school through simple random sampling." Journey to the Matter's Interior Success Test" developed by researchers was used as the measurement tool. In the scoring of the data, "1" was given for each correct answer and "0" for mispriced items. Afterwards, these data were transferred to the computer environment and SPSS (Statistical Package for the Social Sciences) package program was used in the analysis of the data. Frequency (f), percentage (\%), arithmetic mean (X), standard deviation (Sd) were calculated and t test (dependent and independent groups) were used for interpretation of research data. Cohen's d effect size was calculated for the t-test if the differences between the groups or variables were significant. For effect size, Cohen's d values were determined as follows: .20 as small, .50 as medium and .80 as large (Cohen, 1988; Rosenthal, \& Rosnow, 1991).

In primary school science and technology course, the effects of traditional learning and CAI methods on student success and knowledge permanence were investigated. As a result of the research, it is seen that student achievement significantly increased in both traditional learning methods and CAI methods. Technology-enriched learning environments ensure that they are addressed to students with different learning styles, thereby providing positive outcomes in the learning-teaching process. In many researches (Bilgi, \& Şahin, 2012; Erdemir, 2011), it has been seen that the support of teaching designs with technology has changed positively in terms of employee successes, motivations and attitudes towards learning with different learning styles. According to Baki (2002), computer-assisted practices in teaching process reinforce student behaviors and are effective in constructing student's own knowledge. 
Another result of the study is that there is no significant difference between the scores of the post-test and the recall test scores of each group in which traditional learning methods and CAI methods are applied. This shows us that both methods show the same effectiveness at the point of survival of student success. There was no significant difference when the recall test scores of the experimental and control group students were compared within themselves. 


\section{GíRIŞ}

Günümüzde bilgi teknolojilerindeki gelişmeler yaşamın tüm alanlarında olduğu gibi eğitimi de etkilemektedir. Makineler, işlemler, yöntemler, süreçler, sistemler, yönetim ve kontrol mekanizmaları gibi çeşitli öğeleri kapsayan, bu öğelerin belirli bir düzende bir araya getirilmesiyle oluşan ve bilim ile uygulama arasında köprü görevi yapan disipline teknoloji denilmektedir (Alkan, 1998; Topsakal, 2006). Aynı zamanda teknoloji, kendi ön yargıları ile birlikte gelen bir bilgi sistemi olarak da görülmektedir (Koehler, \& Mishra, 2005). Bilgi teknolojilerinin hızla gelişmesi bilgi toplumlarının ortaya çıkmasına sebep olmuş, toplumların teknolojik gelişmeleri izlemeleri ve kendilerine uyarlamalarını zorunlu kılmıştır. Bilgi teknolojilerine duyulan ihtiyaç hem ulusal hem de uluslararası alanda artmaktadır. Bu da ancak bilgi teknolojilerini kullanabilen ve geliştirebilen bireylerin yetiştirilmesiyle gerçekleşebilir. Eğitim teknolojisi araçları olarak kullanılan bilgisayar, veri toplama ve analiz yazılımı, dijital mikroskoplar, hipermedya/multimedya, öğrenci yanıt sistemleri ve interaktif beyaz tahtalar öğrencilerin bilimin doğasına anlamasına ve araştırmasına ve bilimsel bilgiyi elde etmelerine yardımcı olabilir. Eğitim teknolojisi araçları fen sınıflarında uygun ve etkin biçimde kullanıldığı zaman, öğrencilerin aktif olarak bilgiyi kendileri oluşturacak ve bu sayede düşünme ve problem çözme becerileri de gelişecektir (Bybee, Carlson-Powell, \& Trowbridge, 2008). Bilgiye erişim ve bilgi sunumuna farklı bir boyut kazandıran bilgisayarların yaygınlaşmasıyla birlikte, çeşitli teknoloji tabanlı öğretim ortamları da öğretim süreçlerinde kullanılmaya başlanmıştır. Bunlardan biri olan "Bilgisayar Destekli Öğrenme" (BDÖ), bilgisayarın bir öğrenme aracı olarak kullanıldığı, öğrencinin bilgisayarlardan kendi öğrenme hızına göre yararlanabildiği, öğretim sürecini ve öğrenci motivasyonunun güçlendirildiği ve kendi kendine öğrenme ilkelerinin bilgisayar teknolojisiyle birleşmestirildiğibir öğretim yöntemidir (Şahin, \& Yıldırım 1999; Uşun, 2000).

Bilgisayarın eğitimde kullanılmasına ilişkin ilk geniş kapsamlı proje sayılabilen PLATO, üniversitelerin farklı bölümlerinde okuyan öğrencilerin Bilgisayar Destekli Öğrenme (BDÖ) gereksinimini karşılamak amacı ile geliştirilmiştir. Türkiye'deki gelişmeler 1984 yılında ortaöğretim kurumlarına 1100 bilgisayar alınmakla başlamış, ilerleyen zamanlar da ise bilgisayar eğitimi yerine bilgisayarın bir öğrenme aracı olarak kullanıldığı BDÖ uygulamaları başlatılmıştır. BDÖ ile ilgiliçalışmalar incelendiğinde öğrenci ve öğretmen açısından avantajlarının olduğu görülmektedir. BDÖ sayesinde öğrencilerin sürekli aktif tututlmasının yanı sıra, öğrenciler bilgisayarlar vasıtasıyla, araştırdıkları konu ile ilgili sorularına istediği anda ve istediği kadar yanıt alabilmekte ve daha çok bilgiye ulaşma imkanına sahip olmaktadırlar (Altınkaya, 1998; Hızal, 1989; Namlu, 1999; Uşun, 2000). Bu uygulamalar, öğrenenin gözüne hitap etme, öğrenilenleri görselleştirme ve hareketlendirme imkanı sağlamaktadır. Öğrenci, kendisine ait kişisel öğrenme ortamında rahatlıkla çalışabilmektedir. Bilgisayarlar eğitimin bireyselleşmesini sağladığından, her öğrenci kendi yetenek ve kapasitesine göre öğrenme imkanına sahiptir. Bu sayede öğrencinin sosyal iletişim yeteneği gelişir. Öğrenciye bilgiyi belgeleme, dosyalama ve belgelere başvurma alışkanlığı yanında problem çözme ve dikkatini verme yeteneği kazandırır. Hızlı öğrenme ve zamandan tasarruf söz konusudur. Anında dönüt sağladığı için kaçırılan ders veya konu öğrenci tarafindan tekrar edilebilir. Benzeşim sayesinde öğrencilere özgü mekanlar sağlar. BDÖ yöntemi kullanımı öğretmen açısından incelendiğinde ise (Namlu, 1999; Rogers, \& Finlayson, 2002; Uşun 2000), öğretmenden öğretmene değişen öğretimin niteliği BDÖ ile yüksek bir düzeye çıkabilmektedir. Başka bir deyiş̧le, öğretmenlerin derslerinde uyguladıkları öğretim yöntemleri arasındaki olumlu ya da olumsuz farklılıklar BDÖ ile en az düzeye indirilebilmektedir. BDÖ ile sınıfın performansı artar ve öğrenci derse aktif olarak katılır. Bu nedenle öğretmenin işi kolaylaşmakta, öğretmenin farklı seviyelerdeki öğrencilere ayrı ayrı zaman ayırabilme olanağı artmaktadır. Öğretim sürecinde en sıkıcı dersler kolay ve zevkli hale gelir. Konuyu kaçıran öğrenciler, öğretmeni engellemeden konuyu tekrar etme imkanına sahip olabilirler.

Bilgisayarın fen derslerinde kullanılması özellikle konunun gerçekçi ve anlaşılabilir olmasını sağlamaktadır. Soyut oldukları için algılanması zor olan kavramlar bilgisayar sayesinde somutlaştırılabilir. Böylece bilgisayar anlamlı öğrenmeyi kolaylaştırdığı söylenebilir. Morse (1991), bir fen sınıfında bilgisayarın öneminin BDÖ’nün yeterlilikleri ile sınırlandırılamayacağını belirtmiştir. Aksine, bilgisayar kullanımı öğretmenin strateji repertuarına tam öğrenmeyi geliştirecek yeni bir boyut eklenmesini sağlar.

Bilgisayar desteği ile yapılan öğretimde görselliği en fazla olan işlem animasyonlardır. Bilgisayar animasyonu, ekranda bir dizi görüntü ve resmin hızlı bir şekilde gösterilmesidir. Öğretici bilgisayar 
animasyonları, öğrencilerin konuyu daha iyi anlamaları için konuların ve süreçlerin hareketli ve görsel resimleri üzerine inşa edilmelidir. Animasyon bunu en iyi biçimde sağlayarak görsel, çabuk ve özlü bir öğrenim sağlamaya yardımcı olmaktadır. Konuları karikatürize ederek espirili biçimde sunma eğitim sürecini sıkıcılıktan çıkarak sevimli bir hale dönüştürüp öğrenme isteğini artırabilmektedir. Tüm bu özellikleri, hareket halinde ve hareketin doğasını sembolize eden, basit grafik sembollerle renk ve ses eşliği ile sunmaktır (Çakır 1999). Altun, Uysal ve Ünal (1999), hangi yaş grubu için hazırlanırsa hazırlansın, eğitim amaçlı yazılımların yüksek kaliteli ses ve düzenli grafikleri son derece kolay kullanımla birleştirerek sunmaları gerektiğini bildirmiş̧lerdir. Burada hedef, içeriği zengin ama basit, kullanımı kolay ama ilgi çekici materyal üretmekdir.

Öğretmenlik, birçok bilgi alanının bir arada bulunmasını gerektiren bir meslektir. Dolayısıyla geleceğin öğretmenlerinin öğretim sürecinde teknolojiyi etkili bir şekilde derslerine entegre etmesi önemli hale gelmektedir. Öğretmenlerin derslerinde öğretim teknolojilerini etkili bir şekilde kullanmalarının, öğrencilerin öğrenim çıktıları üzerinde de hiç şüphesiz etkili olacağı düşünülmektedir. Şahinkayası ve Şahinkayası (2004)'na göre teknoloji, herhangi bir eğitim kurumunda planlı, etkili ve verimli olarak kullanılırsa, başarıyı artıracağı açıktır. Bir kurum olarak okul, teknolojiyi eğitim programının her alanına entegre etmeli ve bu yolla öğrencilerin aktif ve anlamlı öğrenmelerini desteklemelidir. Öğrencilerin kendi ögrenmelerinden sorumluluk duymaları bu sayede sağlanabilir.

Eğitim konusunda geleneksel yöntemlerle istenen verim ve kaliteye ulaşılmayacağının anlaşılması ile yeni arayışlar içine girilmiş ve teknolojinin etkili bir şeklide kullanılmasını amaçlayanprojeler geliştirilmiştir. Televizyonlu okul gibi uygulamaların yanında üzerinde en çok durulan, konuşulan, tartışılan ve yaygınlaşan uygulama; bilgisayarın eğitimde kullanılması ya da bilgisayar destekli öğretim (BDÖ) olmuştur (Altınkaya 1998). Ayrıca, öğrencinin, fen bilimlerinin önemini anlaması, istenilen davranışları yaşam boyunca kalıcı olarak gösterebilmesi ve bunları geliştirebilmesi için fen konuları ile iç içe olması ve fen konularına dair somut yaşantılarının olması büyük önem taşımaktadır. Bu da fen derslerinde BDÖ uygulamalarına yer vermekle olanaklı hale gelebilecektir (Namlu 1999). Öğrencilerin derslerde verilen bilgileri kalıcı olarak öğrenmelerini sağlamak ve derse karşı ilgilerini sürekli canlı tutmak çok önemlidir. BDÖ bu amaca ulaşmada yaygınlaşan önemli bir araç olarak görülmektedir. Özellikle fen dersleri BDÖ'in uygulaması açısından çok elverişlidir. Bunun nedeni de bilimsel kavram ve prensiplerin bu derslerde oldukça çok olması, bu prensiplerin ögrenciye görsel olarak aktarılabilmesidir (Demircioğlu, \& Geban 1996). Fen konularının (Örneğin: maddenin iç yapısına yolculuk) soyut olması ve öğrencilerin konuları anlama düzeylerinin düşüklüğü bu konuların somutlaştırılmasını zorunlu kılmaktadır. Bu çalışmada da resim, ses ve görüntü effektleriyle zengin bir öğrenme ortamı sağlanarak; çoklu ortam materyallerinin hazırlanması ve bunun sınıf ortamına taşınmasının öğrenci başarısı ve öğrenilenlerin kalıcılığına olan etkisi incelenmiştir.

\section{YÖNTEM}

\section{Araştırma Modeli}

Araştırmada, iki faktörlü karışık desen olarak tanımlanan ön test-son test kontrol gruplu gerçek deneysel desen kullanılmıştır. Gerçek deneysel desende katılımcılar tamamen rastgele seçilirken yarı deneysel desende araştırmacı var olan gruplarda farklı koşulları inceler, bireyleri rastgele seçemez (Plano Clark ve Creswell, 2015). Ön test- son test kontrol gruplu desen, kendi içerisinde hem ilişkili hem de ilişkisiz olarak ele alındığından karışık desen olarak adlandırılır. Denekler deneysel işlem öncesinde ve sonrasında bağımlı değişkenle ilgili olarak ölçüldükleri için ilişkili desen, farklı deneklerden oluşan deney ve kontrol gruplarının ölçümleri karşılaştırıldığı için ilişkisiz desendir (Büyüköztürk, KılıçÇakmak, Akgün, Karadeniz, \& Demirel, 2011). Deneysel desen bağımsız bir yaklaşım değişkeninin (belirli bir öğretim yöntemi) bağımlı bir sonuç değişkeni (akademik başarı) üzerinde bir etkisi olup olmadığına karar vermek için kullanılabilir (Plano Clark, \& Creswell, 2015). Bu araştırma desenlerinde mutlaka karşılaştırma vardır. Bu çalışmada ortaokul 7. sınıf öğrencilerinin "Maddenin İç Yapısına Yolculuk" konusunu öğrenmelerinde geleneksel öğrenme ile bilgisayar destekli öğrenme yöntemlerinin etkisi öğrenci akademik başarısı üzerindeki etkisi incelenmiştir. Bağımsız değişkenlerin (geleneksel ve bilgisayar destekli öğretim yöntemi) bağımlı bir değişken (öğrenci akademik başarısı) üzerindeki etkisi incelendiğinden deneysel desenin kullanılmasına karar verilmiştir. 


\section{Çalışma Grubu}

Araştırma Konya ili Selçuklu ilçesinde bulunan bir devlet okulunda yürütülmüştür. Çalışmanın deney $(\mathrm{N}=23)$ ve kontrol $(\mathrm{N}=23)$ grupları basit seçkisiz örnekleme yöntemi kapsamında belirlenmiştir. Basit seçkisiz örnekleme (simple random sampling) yönteminde çalışma grubuna seçilecek olan tüm bireyler eşit ve bağımsız bir şansa sahiptir. Diğer bir değişle, tüm bireylerin seçilme olasılığı aynıdır ve bir bireyin seçimi diğer bireylerin seçimini etkilememektedir (Arıkan, 2013; Büyüköztürk, vd. 2011; Ekiz, 2009). Temsil edici bir örneklemin seçiminin geçerli ve en iyi yolu olarak basit seçkisiz örnekleme yöntemi olarak görülmektedir (Büyüköztürk vd. 2011). Bu kapsamda, bir devlet okulunda öğrenim görmekte olan 7. sınıf öğrenci grupları arasından basit seçkisiz örnekleme kapsamında deney $(\mathrm{N}=23)$ ve kontrol $(\mathrm{N}=23)$ grupları çalışma grubuna dâhil edilmiştir.

\section{Veri Toplama Aracı ve Geliștirilmesi}

$\mathrm{Bu}$ Araştırmada, uzman görüşleri doğrultusunda çoklu ortam materyallerinin geliştirilmesi ve bu materyallerin bilgisayar ortamında öğrencilere sunulması ve bu ortamların öğrencilerin akademik başarısı üzerindeki etkisinin incelenmesi hedeflenmiştir. Araştırmada öğrencilerin akademik başarı düzeylerini ölçmek için "Maddenin İç Yapısına Yolculuk" ünitesini kapsayan, öntest, sontest ve hatırlama testi olarak kullanılmak üzere taslak çoktan seçmeli bir başarı testi geliştirilmiştir. Taslak başarı testinin hazırlanmasında Tekin (2003) tarafından ortaya konan adımlar göz önüne alınmıştır. Bu adımlar; (1) Testin kullanılacağı amacın belirlenmesi, (2) Testte bulunacak soru sayısının kararlaştırılması, (3) Ölçülecek davranışlar ve bu davranışların hangi içerik içinde ölçüleceğinin belirlenmesi, (4) Kullanılacak soru tipinin belirlenmesi, (5) Testin güçlülüğü ve testte bulunacak soruların güçlük dağılımının belirlenmesi (6) Puanlama işleminin yapılması olarak belirlenmiştir. İlk olarak programda yer alan kazanımlar doğrultusunda 40 maddelik taslak halinde bir "Akademik Başarı Testi" hazırlanmıştır. Taslak olarak hazırlanan başarı testinde yer alan maddelerin geçerliği ve güvenirlik çalışmaları yapılmıştır. Taslak ölçme aracının kapsam geçerliğiyle ilgili olarak uzman görüşlerine başvurulmuş ve uzmanlara ölçekte yer alan her bir madde Fen Bilimleri dersi öğretim programı kazanımları çerçevesinde "uygun", "uygun değil” ve "geliştirilmesi gerekir" seçeneklerinde değerlendirmeleri istenmiştir. Uzmanlardan gelen dönütler doğrultusunda uzmanlar arasındaki tutarlılık sağlanarak ölçme aracının kapsam geçerliği sağlanmıştır.

Taslak olarak hazırlanan “Akademik Başarı Testi”nin ön uygulaması, araştırma grubunda yer almayan bir devlet okulunda okumakta olan 114 kişilik 8. sınıf öğrencisine uygulanmıştır. Uygulama sonrasında testte anlaşılmayan ve güvenirliği düşüren 15 adet madde çıkarılarak, testteki soru sayısı 25'e düşürülerek çoktan seçmeli olarak son hali verilmiştir. Kalan 25 soru üzerinden ölçme aracının KR-20 güvenirlik kat sayısı.824 olarak hesaplanmıştır. Elde edilen bu güvenirlik katsayısına göre son hali verilen akademik başarı testinin yüksek derecede güvenilir olduğu söylenebilir (Kalaycı, 2010; Özdamar, 2004).

\section{Bağlam}

Araştırma Konya ili Selçuklu ilçesinde bir devlet okulunda gerçekleştirilmiştir. Okul, ilçe merkezi okullarından biri olarak eğitim vermektedir ve okulda 24 derslik, 1 Fen Bilimleri laboratuvarı, farklı branşlarda toplam 68 öğretmen ve 1326 öğrenci bulunmaktadır. Görev yapmakta olan öğretmenlerden 4'ü Fen Bilimleri öğretmenidir. Ayrıca, 7. sınıfta öğrenim görmekte olan 140 öğrenci ve 4 şube (A, B, C, D) yer almaktadır. Araştırmanın gerçekleştirildiği dönemde okulda öğrenci ya da öğretmenlerin kullanabileceği bilgisayar laboratuvarı ya da teknoloji sınıfları bulunmamaktadır. Okulda sadece bir adet laboratuvar vardı ve bu laboratuvar da okul-aile işbirliği ile 2005 yılında kurulmuştu. Laboratuvarda fen öğretimine ile ilgili araç-gereçler incelendiğinde, bazı deney etkinliklerini yapmaya/yaptırmaya yönelik laboratuvar malzemelerinin oldukça yetersiz olduğu söylenebilir. Ayrıca, fen öğretimine yönelik laboratuvarın öğretmenler tarafından çok fazla tercih edilmediği görülmektedir. $\mathrm{Bu}$ nedenle fen öğretiminde öğretmenlerin ders araç-gereçlerini derse taşımadıkları ve derste bunları kullanmadıkları görülmüştür. Öğrencilerin öğretim teknolojileri ve materyaller ile fen öğrenmeye ilişkin hiç bir deneyimleri bulunmamamaktadır.

\section{Veri Toplama Süreci}

Araştırma sürecinde belirlenen deney ve kontrol grubu öğrencilerine ikinci yazar tarafindan 8 haftalık eğitim-öğretim süresince "Maddenin İç Yapısına Yolculuk" konusunun öğretimi gerçekleştirilmiştir. Bu 
konu temel iki başlık altında öğretimi gerçekleştirilmiştir: (a) Maddelerin Sınıflandırılması ve Dönüşümleri (Maddelerin Katı, Sıvı ve Gaz Olarak Sınıflandırılması, Fiziksel ve Kimyasal Değişmeler, Karışımların Fiziksel Yolla Ayrılması, Bileşiklerin Kimyasal Yolla Ayrıştırılması, Elementlerden Bileşik Oluşturulması) ve (b) Atomun Yapısı ve Periyodik Çizelge (Atomun Yapısı, İyonlar Atomların Elektrik Yüklü Hâlleridir, Bir Elementin Birden Çok İzotopu Olabilir, Elementler Kendi Aralarında Sınıflara Ayrılır, Tüm Elementler Periyodik Çizelgede Gösterilir).

Deney grubu öğrencileri için konunun öğretiminde bilgisayar ve bilgisayar yazılımları (Adobe Flash, Microsoft Office) ile birlikte projeksiyon cihazı ve ses çıkışı için speaker kullanılmıştır (Bilgi, \& Şahin, 2012). Bu grupta yapılacak olan öğretim için ders içerikleri oluşturulduktan sonra power point programında haftalık olarak görsel olarak sunular hazırlanmıştır. Hazırlanan bu sunularla birlikte ders anlatımları gerçekleştirilmiştir. Ayrıca, bazı kazanımlara yönelik etkinliklere (Karışımların fiziksel yollarla ayrılması; mıknatıs, eleme, süzme, yüzdürme, damıtma, vb) ilişkin Adobe Flash programında hazırlanan simulasyonlar ders anlatımı esnasında öğrencilere izletilerek öğrenme sürecinin daha eğlenceli ve öğrenmenin kalıcılığ 1 amaçlanmıştır. Çakır (1999), animasyonların öğrencinin ders konularını somut olarak izleyerek kavramalarının yanında, yaratıcı düşünmelerine, olasılıklar üzerinde durmalarına, çeşitli denemelere girmelerine de yardım ettiğini belirtmiştir. Animasyonlar geleneksel sınıf ortamının sıkıcılığını büyük ölçüde ortadan kaldırarak, öğrenme etkinliklerini zevkli bir uğraş haline getirmektedir. Araştırmada yer alan deney grubu öğrencilerinin ilk defa teknoloji açısından zenginleştirilmiş bir sınıf ortamında fen öğreniyor olmaları da çalışmanın önemini arttırmaktadır. Bilgisayar ortamında hazırlanan konular hareketli, ilgi çekici, öğrencinin kolay anlayabileceği şekilde dizayn edilmiştir. Sunular içerisinde problem çözme, deney yapma ve öğrencileri soru sormaya cesaretlendirecek faaliyetlere yer verilmiştir.

Kontrol grubunda da aynı araştırmacı tarafından "Maddenin İç Yapısına Yolculuk" konusuna yönelik aynı kazanımları vermek üzere geleneksel öğretim yöntemlerinin (öğretmen merkezli ve bilgilerin öğretmen tarafından öğrencilere yazdırılması) kullanıldığı bir öğretim yapılmıştır. Bu sınıfta araştırmacı haftalık ders planı çerçevesinde kazanımları öğretmen merkezli bir öğretim yaklaşımı ile vermiştir. Bu sınıfta herhangi bir öğretim materyali ya da teknolojisi kullanılmamıştır.

\section{Verilerin Analizi}

Hazırlanan çoktan seçmeli "Maddenin İç Yapısına Yolculuk Başarı Testi"nin güvenirlik hesaplamalarının yapılmasından sonra bu testler deney ve kontrol grubu öğrencilerine ayrı ayrı ön test, son test ve hatırlama testi olarak uygulanmıştır. Deney ve kontrol gruplarından "Maddenin İç Yapısına Yolculuk Başarı Testi" ile elde edilen veriler birbirinden ayrı ele alınmıştır. Uygulanan çoktan seçmeli "Maddeninİç Yapısına Yolculuk Başarı Testi"nden elde edilen verilerin her bir maddesi titizlikle incelenmiş olup, puanlama, bu başarı testi maddelerinde, her bir doğru cevap için "1", yanlış veya boş bırakılan, (verilen cevaplar hazırlanan cevap anahtarı ile karşılaştırılarak puanlama yapılmıştır.) maddeler için “0” verilerek yapılmıştır.

$\mathrm{Bu}$ çalışmada elde edilen verilerin analizinde SPSS paket programı kullanılmıştır. Verilerin çözümlenmesi işlemine geçilmeden önce toplanan veriler bilgisayar ortamında SPSS paket programına girilmiştir. Daha sonra veriler üzerinde genel bir değerlendirme yapılarak kayıp değerlerin (missing value) olup olmadığı incelenmiştir. Bu değerlendirme sonrasında ise verilerin normal dağılım gösterip göstermediği Shapiro Wilk testi ile değerlendirilmiştir (Kalayc1, 2010). Araştırma verilerinin yorumlanmasında frekans (f), yüzde (\%), aritmetik ortalama (X), standart sapma (Sd) hesaplanmış ve ikili değişkenler için t testi (bağımlı ve bağımsız gruplar) kullanılmıştır. Yapılan analizler sırasında gruplar ya da değişkenler arasındaki farkın anlamlı çıkması durumunda, t-testi için Cohen's d etki büyüklüğü hesaplanmıştır. Etki büyüklüğü için Cohen's d değerleri .20 (small), .50 (medium) ve .80 (large) değerleri sırasıyla küçük, orta ve büyük olarak tanımlanmıştır (Cohen, 1988; Rosenthal, \& Rosnow, 1991).

\section{BULGULAR}

Araştırmanın bu bölümünde temel problem olarak "İlköğretim Fen Bilimleri öğretiminde, geleneksel öğretim yöntemleri ile Bilgisayar Destekli Öğretim (BDÖ) yöntemlerinin öğrenci başarısı üzerindeki etkisinde anlamlı bir farklılık var mıdır?" sorununa cevap aranmıştır. Çalışmanın uygulamalarına geçmeden önce deney ve kontrol grubu öğrencilerine“Madenin İç Yapısına Yolculuk Ünitesi Akademik 
Başarı Testi” ön test olarak uygulanmıştır. Sekiz haftalık öğretim süreci sonrasında öğrencilerin ulaştıkları bilgi seviyesini belirlemek için daha önce kullanılan "Madenin İç Yapısına Yolculuk Ünitesi Akademik Başarı Testi" son test olarak uygulanmıştır. Son olarak, çalışmanın bitiminden 8 hafta sonra deney ve kontrol grubu öğrencilerine aynı test hatırlama testi olarak tekrar uygulanmıştır. Deney ve kontrol grubu öğrencilerinden elde edilen verilere ilişkin analiz sonuçları alt başlıklar halinde verilmiştir.

\section{Deney ve kontrol gruplarının betimsel analiz sonuçları}

Deney ve kontrol grubunda yer alan öğrencilerin cinsiyet açısından karşılaştırılması Tablo 1'de verilmiştir.

Tablo 1. Deney ve Kontrol Grubunun Cinsiyete Göre Dağıllmmları

\begin{tabular}{lllll}
\hline Grup & $\mathrm{N}_{(\mathrm{K} \text { iz) }}$ & $\mathrm{N}_{\text {(Erkek) }}$ & $\mathrm{N}_{\text {(Toplam) }}$ & $\%$ \\
\hline Deney Grubu & 11 & 12 & 23 & 50 \\
Kontrol Grubu & 12 & 11 & 23 & 50 \\
Toplam & 23 & 23 & 46 & 100 \\
\hline
\end{tabular}

Tablo 1 incelendiğinde, deney ve kontrol grubundan çalışmaya katılan öğrencilerin sayısal olarak eşit olduğu görülmektedir. Deney grubunda yer alan öğrencilerin 11'i kız, 12'si ise erkek öğrenci olmak üzere toplam 23 öğrenci yer almaktadır. Kontrol grubunda ise 12 kı öğrenci, 11 erkek öğrenci olmak üzere toplam 23 öğrenci bulunmaktadır.

Deney ve kontrol grubu öğrencilerinin ön test, son test ve hatırlama testi başarı puanlarına ilişkin betimsel analiz sonuçları Tablo 2'de verilmiştir.

Tablo 2. Deney ve Kontrol Grubu Betimsel Analiz Sonuçları

\begin{tabular}{lllllll}
\hline & \multicolumn{2}{l}{ Ön Test } & \multicolumn{2}{c}{ Son Test } & \multicolumn{2}{c}{ Hatırlama Testi } \\
\hline Grubu & $\mathrm{X}$ & $\mathrm{Sd}$ & $\mathrm{X}$ & $\mathrm{Sd}$ & $\mathrm{X}$ & $\mathrm{Sd}$ \\
\hline Deney Grubu & 7.30 & 2.46 & 11.65 & 3.18 & 11.17 & 2.32 \\
Kontrol Grubu & 7.30 & 2.53 & 10.39 & 2.62 & 10.13 & 3.58 \\
\hline
\end{tabular}

Deney ve kontol grubu öğrencilerinin başarı puan ortalamalarını gösterenTablo 2 incelendiğinde, öntest puanlarının aynı $(X=7.3)$ olduğu görülmektedir. Öğrencilerin son test başarı puan ortalamalarında deney $(X=11.65 ; S d=3.18)$ ve kontrol $(X=10.39 ; S d=2.62)$ grubu arasında farklılaşmanın olduğu görülmektedir. Benzer şekilde hatırlama testi puan ortalamalarında da deney $(X=11.17 ; \mathrm{Sd}=2.32)$ ve kontrol $(X=10.13 ; \mathrm{Sd}=3.58)$ grupları arasında fark olduğu görülmektedir.

Deney ve kontrol grubu ön test puanlarının karşılaştırılması

Deney ve kontrol grubu öğrencilerinin ön test başarı puanlarına ilişkin bağımsız gruplar için t-testi analiz sonuçları Tablo 3'te verilmiştir.

Tablo 3. Deney ve Kontrol Grubu Ön Test Başarı Puanlarına İlişkin t-Testi Analiz Sonuçları

\begin{tabular}{lllllll}
\hline Uygulama & Grup & $\mathrm{N}$ & $\mathrm{X}$ & $\mathrm{Sd}$ & $\mathrm{t}$ & $\mathrm{p}$ \\
\hline \multirow{2}{*}{ Ön Test } & Deney Grubu & 23 & 7.30 & 2.46 & \multirow{2}{*}{00} & .809 \\
& Kontrol Grubu & 23 & 7.30 & 2.53 & & \\
\hline
\end{tabular}

Tablo 3 incelendiğinde, deney $(X=7.3 ; \mathrm{Sd}=2.46)$ ve kontrol $(\mathrm{X}=7.3 ; \mathrm{Sd}=2.53)$ grubu öğrencilerinin ön test başarı puan ortalamaları arasında istatistiki olarak anlamlı bir farklılık görülmemiştir $(\mathrm{t}=.00 ; \mathrm{p}>$ .05). Sonuçta, deney ve kontrol grubunda bulunan öğrencilerinin, ön test puanları birbirine eşit olduğundan bu sınıfların birbirine denk olduğu söylenebilir.

\section{Deney ve Kontrol grubu ön test-son test puanlarının karşılaş̧ırııması}

İlkögretim 7. Sınıf Fen Bilimleri dersi Maddenin İç Yapısına Yolculuk ünitesinde deney grubu öğrencilerinin ön test-son test başarı puan ortalamalarına ilişkin bağımlı gruplar için t-testi analiz sonuçları Tablo 4'te verilmiştir. 
Tablo 4. Kontrol Grubu Öğrencilerinin Ön Test ve Son Test Puanlarina İlişkin t-Testi Analiz Sonuçları

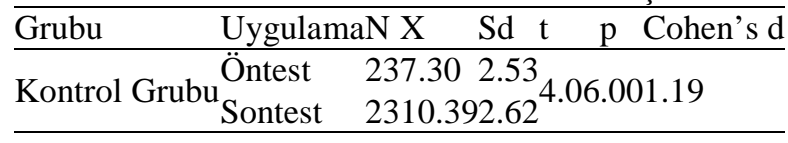

Tablo 4'te görüldüğü gibi kontrol grubu öğrencilerinin ön test $(X=73 ; S d=2.53)$ ile son test $(X=10.39$; $\mathrm{Sd}=2.62)$ puan ortalamaları arasında son test lehine $\left(\mathrm{X}_{\text {SonTest-Ön Tes }}=3.09\right)$ istatistiki olarak anlamlı bir farkın oluştuğu görülmektedir $(\mathrm{t}=4.06 ; \mathrm{p}<.05)$. Başka bir ifade ile kontrol grubunda kullanılan geleneksel öğretim yöntemlerinin öğrenci başarısının artmasında etkili olduğu söylenebilir. Ayrıca, ön test ve son test puanları arasında ortaya çıkan farkı netki büyüklüğü Cohen d değeri ile hesaplanmıştır. Etki büyüklüğünün ( $\mathrm{d}=1.19)$ büyük (large) etki büyüklüğüne sahip olduğu görülmektedir.

İlköğretim 7. Sınıf Fen Bilimleri dersi Maddenin İç Yapısına Yolculuk ünitesinde deney grubu öğrencilerinin ön test-son test başarı puanlarına ilişkin bağımlı gruplar için t-testi analiz sonuçları Tablo 5’te verilmiştir.

Tablo 5. Deney Grubu Öğrencilerinin Ön Test- Son Test Başari Puanlarina İlişkin t-Testi Analiz Sonuçlari

\begin{tabular}{llllll}
\hline Grubu & UygulamaN X & sd & t & p & Cohen’s d \\
\hline \multirow{2}{*}{ Deney Grubu Öntest } & 237.30 & $2.45^{5.48 .001 .53}$ \\
& Sontest & $2311.653 .18^{5.48 .001 .53}$ \\
\hline
\end{tabular}

Tablo 5'te görüldüğü gibi deney grubu öğrencilerinin ön test $(X=7.3 ; S d=2.45)$ ve son test $(X=11.65$; $\mathrm{Sd}=3.18)$ puan ortalamaları arasında son test puanları lehine $\left(\mathrm{X}_{\text {SonTest-Ön Test }}=4.35\right)$ istatistiki olarak anlamlı bir farkın oluştuğu görülmektedir $(\mathrm{t}=5.48 ; \mathrm{p}<.05)$. Başka bir ifadeyle deney grubu öğrencilerinde konunun öğretimine ilişkin kullanılan Bilgisayar Destekli Öğretme yönteminin öğrenci başarısını arttırdığı söylenebilir. Ayrıca, ön test ve son test puanları arasında ortaya çıkan farka ilişkin etki büyüklüğünün hesaplandığg Cohen d değeri incelendiğinde, $(\mathrm{d}=1.53)$ geniş (large) etki büyüklüğüne sahip olduğu görülmektedir.

Deney ve kontrol grubu öğrencilerinin son test başarı puan ortalamalarına ilişkin bağımsız gruplar için t-testi analiz sonuçları Tablo 6'da verilmiştir.

Tablo 6. Deney ve Kontrol Grubu Öğrencilerinin Son Test Başarı Puanlarına İlişkin t-Testi Analiz Sonuçları

\begin{tabular}{lllllll}
\hline Uygulama & Grup & $\mathrm{N}$ & $\mathrm{X}$ & $\mathrm{sd}$ & $\mathrm{t}$ & $\mathrm{p}$ \\
\hline \multirow{2}{*}{ Son Test } & Deney Grubu & 23 & 11.65 & 3.18 & \multirow{2}{*}{1.46} & \multirow{2}{*}{.150} \\
& Kontrol Grubu & 23 & 10.39 & 2.62 & & \\
\hline
\end{tabular}

Tablo 6 incelendiğinde, deney $(X=11.65 ; \mathrm{Sd}=3.18)$ ve kontrol $(X=10.39 ; \mathrm{Sd}=2.62)$ grubu öğrencilerinin son test puan ortalamaları deney grubu öğrenci puanları lehine $(X=1.26)$ olmasına rağmen bu farkın istatistiki olarak anlamlı olmadığı görülmüştür ( $\mathrm{t}=1.46 ; \mathrm{p}>.05)$. Bu sonuca göre, deney ve kontrol gruplarında uygulanan öğretim yöntemlerinin (geleneksel ve bilgisayar destekli öğretme) öğrenci başarısı üzerindeki etkisinin anlamlı bir farklılık oluşturmadığı görülmüştür.

\section{Deney ve kontrol grubu hatırlama testi puanlarının karşılaştırılması}

Kontrol grubu öğrencilerinin son test ve hatırlama testi başarı puanlarına ilişkin bağımlı gruplar için ttesti analiz sonuçları Tablo 7'de verilmiştir.

Tablo 7. Kontrol Grubu Öğrencilerinin Son Test ve Hatırlama Testi Başari Puanlarina İlişkin t-Testi Analiz Sonuçları

\begin{tabular}{|c|c|c|}
\hline Grubu & Uygulama & $\begin{array}{lll}\mathrm{sd} & \mathrm{t} & \mathrm{p}\end{array}$ \\
\hline Kor & $\begin{array}{c}\text { Sontest } \\
\mathrm{u}_{\text {Hatırlama }}\end{array}$ & $\begin{array}{r}2310.392 .62 \\
\text { ti2310.133.58 }\end{array}$ \\
\hline
\end{tabular}

Tablo 7'de kontrol grubu öğrencilerinin son test $(X=10.39 ; S d=2.62)$ ve hatırlama testi puan $(X=10.13$; $\mathrm{Sd}=3.58)$ ortalamalar1 arasinda son test puanları lehine farkl11ı $\left(\mathrm{X}_{\text {SonTest-Hatrlama Testi }}=.26\right)$ olmasina rağmen bu farkın istatistiki olarak anlamlı olmadığı görülmektedir $(\mathrm{t}=.282 ; \mathrm{p}>.05)$. Başka bir ifadeyle 
kontrol grubu öğrencilerinin son testte elde edilen bilgi düzeylerinin korunduğu, hatırlandığı söylenebilir. Bu durum da öğrenci öğrenmelerinde kalıcı öğrenmenin gerçekleştiği söylenebilir.

Deney grubu öğrencilerinin son test ve hatırlama testi başarı puanlarına ilişkin bağımlı gruplar için ttesti analiz sonuçları Tablo 8'de verilmiştir.

Tablo 8. Deney Grubu Öğrencilerinin Son Test ve Hatirlama Testi Başari Puanlarina İlişkin t-Testi Analiz Sonuçları

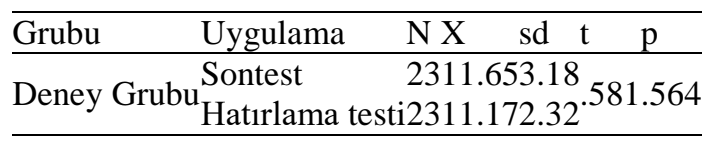

Tablo 8 incelendiğinde, deney grubu öğrencilerinin son test $(X=11.65 ; \mathrm{Sd}=3.18)$ ve hatırlama testi $(\mathrm{X}=11.17 ; \mathrm{Sd}=2.32)$ başarı puan ortalamaları arasında son test puan ortalamaları lehine $\left(\mathrm{X}_{\text {SonTest- Hatrlama }}\right.$ Testi $=.48)$ bir fark olmasına rağmen bu farkın istatistiki olarak anlamlı olmadığı görülmektedir $(\mathrm{t}=.581$; $\mathrm{p}>$.05). Başka bir ifadeyle deney grubu öğrencilerinin öğrenmesinde kullanılan bilgisayar destekli öğretim yönteminin öğrenci başarısında kalıc1lı olduğu söylenebilir.

Maddenin İç Yapısına Yolculuk ünitesinde deney ve kontrol grubu öğrencilerinin hatırlama testi başarı puanlarına ilişkin bağımsız gruplar için t-testi analiz sonuçları Tablo 9'da verilmiştir.

Tablo 9. Deney ve Kontrol Grubu Öğrencilerinin Hatırlama Testi Başarı Puanlarına İlişkin t-Testi Analiz Sonuçları

\begin{tabular}{lllllll}
\hline Uygulama & Grup & $\mathrm{N}$ & $\mathrm{X}$ & $\mathrm{sd}$ & $\mathrm{t}$ & $\mathrm{p}$ \\
\hline \multirow{2}{*}{ Hatırlama Testi } & Deney Grubu & 23 & 11.17 & 2.82 & \multirow{2}{*}{1.17} & \multirow{2}{*}{248} \\
& Kontrol Grubu & 23 & 10.13 & 3.58 & & \\
\hline
\end{tabular}

Tablo 9'da gibi deney $(X=11.17$; $S d=2.82)$ ve kontrol $(X=10.13$; $S d=3.58)$ grubu öğrencilerinin hatırlama testi puan ortalamalarının, deney grubu öğrenci puanları lehine $(X=1.04)$ olmasına rağmen istatistiki olarak bu farkın anlamlı olmadığı görülmektedir $(\mathrm{t}=1.17 ; \mathrm{p}>.05)$. Bu sonuç deney ve kontrol gruplarında kullanılan öğretim yöntemlerinin öğrenci öğrenmeleri kalıcılığında bir farklılık oluşturmadığı şeklinde yorumlanabilir. Her iki öğretim yönteminin de öğrenci öğrenmelerinin kalıcılığında eşit düzeyde etkili olduğu söylenebilir.

\section{TARTIŞMA ve SONUÇLAR}

$\mathrm{Bu}$ çalışmada ortaokul Fen Bilimleri dersinde geleneksel öğrenme yöntemleri ile bilgisayar destekli öğrenme yöntemlerinin öğrenci başarısı ve bilginin kalıcılığı üzerindeki etkisi araştırılmıştır. Araştırma sonucunda geleneksel öğrenme yöntemleri ile bilgisayar destekli öğrenme yöntemlerinin her ikisinde de öğrenci başarısını anlamlı olarak arttırdığı görülmüştür. Teknoloji ile zenginleştirilmiş öğrenme ortamları farklı öğrenme stillerine sahip öğrencilere hitap edilmesini, dolayısıyla öğrenme-öğretme sürecinde olumlu sonuçların çıkmasını sağlamaktadır. Yapılan birçok araştırmada (Bilgi, \& Şahin, 2012; Erdemir, 2011) öğretim tasarımlarının teknoloji ile desteklenmesi sonucu farklı öğrenme stillerine sahip öğrenci başarılarının, motivasyonlarının ve öğrenmeye karşı tutumlarının olumlu yönde değiştiği görülmüştür. Liao (2007), yaptığı araştırmada öğretmenlerin derslerinde kullandıkları teknolojileri öğretimi olumlu bir şekilde etkilediğini belirtmişlertir. Baki (2002)'ye göre öğretim sürecinde bilgisayar destekli uygulamaların öğrenci davranışlarını pekiştirmede ve öğrencinin bilgiyi kendisinin yapılandırmasında etkili olmaktadır.

Kartal (2007) tarafından ortaokul 8. sınıf öğrencilerinde yapılan çalışmada genetik ünitesinin öğretimine yönelik aktif öğrenme teknikleri kullanılmıştır. Aktif öğrenme teknikleri çerçevesinde DNA ve RNA görsel modelleri öğrenci öğrenmelerinde kullanmıştır. Bu öğretim materyalleri öğrenci öğrenmeleri ve tutumları üzerinde olumlu ve istatistiki olarak anlamlı bir farklık göstermiştir. Ayrıca, öğrenci öğrenmeleri noktasında bu öğretim materyallerinin kullanımı ile öğrenmenin kalıcılığının sağlandığı da söylenebilir. Demirbaş ve Demirkan (2003)'a göre teknolojilerle desteklenen öğretim tasarımları sonucunda öğrenci akademik başarısının ve performansının arttığı gözlenmektedir. Güven ve Sülün (2012) tarafından yapılan benzer bir araştırmada, bilgisayar destekli öğretim yönteminin uygulandığı deney grubu öğrencilerinin son test başarı puanları ile geleneksel öğretim yöntemlerinin kullanıldığı kontrol grubu ögrencilerinin son test başarı puanları arasında deney grubu lehine anlamlı bir farklılaşmanın olduğu görülmüştür. Bu durumun nedeni olarak, öğretmenin konuyu işlerken gerekli 
durumlarda bilgisayarı yardımcı bir araç olarak kullanmasıyla soyut kavramların daha somut hale getirilerek öğretimi desteklemesinin gösterilebileceği ifade edilmiştir. Özmen ve Kolomuç (2004) tarafından yapılan çalışmada ise, çözeltiler konusunun bilgisayarla ve geleneksel yöntemlerle öğretilmesinin öğrencilerde meydana getirdiği öğrenmelerin karşılaştırılması amaçlanmıştır. Araştırma sonuçları, bilgisayarla öğretilen öğrencilerin açık uçlu sorulardaki başarılarının geleneksel yolla öğretilen öğrencilere oranla daha yüksek düzeyde olduğunu göstermiştir. Hem deney hem de kontrol grubu öğrencilerine ön test ve son test olarak uygulanan çoktan seçmeli testten elde edilen veriler karşılaştırıldığında, ön testte deney grubu öğrencilerinin sorulara verdikleri doğru cevap oranları \%10 ile \%68 arasında değişirken, bu oranlar kontrol grubu öğrencileri için \%13 ile \%75 arasında değişmektedir. $\mathrm{Bu}$ durum öğrencilerin başlangıç seviyeleri arasında büyük bir farklılık olmadığını göstermektedir. Uygulama sonrasında, testin çoktan seçmeli bölümünden elde edilen veriler gruplar arasında anlamlı bir fark olmadığını gösterirken, açık uçlu bölümden elde edilen verilerin karşılaştırılması sonucu deney ve kontrol grubu öğrencileri arasında deney grubu lehine anlamlı bir farklılık olduğu sonucuna ulaşılmıştır. Bilgi ve Şahin (2012) tarafından elde edilen araştırma sonuçlarına göre, öğrencilerin derse aktif katılımlarının sağlanmasında bilgisayar destekli öğretimin geleneksel öğretime göre daha başarılı olduğu söylenebilir. Soru bazında yapılan incelemelerin sonuçlarına göre, kullanılan animasyonların konuyla ilgili daha az kavram yanılgısı oluşturduğu sonucuna ulaşılmıştır.

Ayrıca, geleneksel öğrenme ve bilgisayar destekli öğrenme ortamlarında öğrenci öğrenmelerinde meydana gelen olumlu değişime ilişkin etki büyüklügü indekslerinden cohen d değeri hesaplanmış ve her iki grupta da meydana gelen olumlu değişmenin büyük etki büyüklüğüne sahip olduğu görülmüştür. Öğretmen ve öğretmen adaylarının öğretim sürecinde teknoloji kullanımına ilişkin yapılan benzer çalışmalarda (Kartal, \& Afacan, 2017) orta düzeyde etki büyüklüğünün ortaya çıktığı görülmektedir. Araştırmanın diğer bir sonucunda ise geleneksel öğrenme yöntemleri ile bilgisayar destekli öğrenme yöntemlerinin uygulandığı her bir grubun kendi içerisinde son test puanları ile hatırlama testi puanları arasında anlamlı bir farklılık görülmemiştir. Bu durum her iki yönteminde öğrenci başarısının kalıcılığı noktasında aynı etkiyi gösterdiği şeklinde yorumlanabilir. Deney ve kontrol grubu öğrencilerinin hatırlama testi puanları kendi içerisinde karşılaştırıldığında da anlamlı bir farklılık bulunmamıştır. Yaşanan bu başarısızlığın temel nedeni olarak, okullarda teknolojiye erişimin iyileştirilmesine rağmen, öğretmenlere teknolojiyi sınıfta nasıl kullanacakları ve teknolojiyi derslerine nasıl entegre edebilecekleri konusunda yeterli destek verilememiş olması gösterilebilir (Sheingold, Heller, \& Paulukonis, 1995). Şeker, Yener ve Özkaya (2002) 235 fen bilgisi öğretmeni üzerinde anket uygulayarak yaptıkları bir araştırmada, bu öğretmenlerin \% 61.3'ünün çalıştığı okulda bilgisayar bulunduğunu, ancak bunlardan sadece \% 7.2'sinin bu imkanı ders anlatımında kullandığını tespit etmişlerdir. Bu araştırma sonucu öğretmenlerin BDÖ yöntemine karşı ilgisiz kaldıklarını göstermektedir. Bu konuda Uçar (1999) tarafından yapılan bir başka çalışmada da öğretmenlerin BDÖ yöntemiyle ders anlatmaya yeterince ilgili göstermedikleri ifade edilmiştir.

\section{Sinırlılıklar ve Öneriler}

Araştırma kapsam açısından, ortaokul Fen Bilimleri dersi öğretiminde bilgisayar destekli ve geleneksel öğretim yöntemlerinin öğrencilerin ortaokul Fen Bilimleri dersi Maddenin İç Yapısına Yolculuk konusunu öğrenmelerine olan etkisisinin incelenmesi ile sinırlıdır.

Araştırma yöntem açısından, kontrol gruplu öntest ve sontest deneysel araştırma modeliyle sınırlıdır. Bu çalışmada deney ve kontrol gruplarında uygulanan geleneksel ve bilgisayar destekli öğrenme yöntemlerinin her ikisinde de aynı kazanımlar aynı araştırmacı tarafından ele alınmıştır. Aynı araştırmacının öğretmen olarak bu sınıflarda öğretim yapması belki de araştırmacı yanlılığını ön plana çıkartabilir. Çalışma gruplarında araştırmacı yanlılığını ortadan kaldırmak amacıyla benzer bir çalışmada yöntemsel olarak solomon üçlü ya da dörtlü gruplar kullanılabilir. Solomon üçlü grupta iki deney, bir kontrol grubu kullanılarak deney gruplarından diğerine başka bir araştırmacı ya da öğretmenin girmesi sağlanabilir. Solomon dörtlü deneysel desende ise iki deney, iki kontrol grubunun olduğu benzer çalışmalar tasarlanabilir (Campbell, \& Stanley, 1963; Whitman, Van Rooy, Viswesvaran, \& Alonso, 2008). Böylece herbir deney-kontrol grubuna araştırmacı ile birlikte bir öğretmenin girmesi sağlanark araştırmacı yanlılığını ortadan kaldırmaya yönelik bir önlem alınmış olacaktır. Bu durumun aynı zamanda araştırmanın genellenebilirliğini de arttıracağı düşünülmektedir.

Çalışma, veri toplama teknikleri açısından "Maddenin İç Yapısına Yolculuk" isimli akademik başarı testi ölçeği ile sınırlıdır. Bu konunun öğretim sürecinde öğrenci başarılarını değerlendirmek amacıyla 
ürün değerlendirmeye yönelik ölçme araçları ile birlikte süreç değerlendirmeyi de ön plana çıartan ölçme araçları da kullanılabilir.

$\mathrm{Bu}$ çalışmada öğretim yöntemlerinin öğrenci başarıları üzerindeki değişim incelenerek daha çok öğrenci bilişsel süreçleri üzerine yoğunlaşılmıştır. Fakat çalışmada öğrenci inanç sistemleri ve tutumları göz önüne alınmamıştır. Sonraki yapılacak olan çalışmalarda öğrenci ve öğretmenlerin öğrenme ve öğretme sürecinde teknoloji kullanımına ilișkin inanç sistemleri ve tutumları incelenebilir.

Eğitimin en önemli öğelerinden birisinin öğretmen olduğu düşünülecek olursa, öğretmenlerin teknoloji kullanımına yönelik yeterliklerinin geliştirilmesi öğrenci başarısı üzerinde önemli bir faktördür. Bu nedenle öğrenci öğrenmelerini arttırmak ve bu öğrenmelerin kalıcılığını sağlamada öğretmenlerin sınıf ortamında bilgisayar destekli öğretim yöntemlerini kullanabilecekleri fiziksel ortamların sağlanması ile birlikte öğretmen yeterliklerinin de bu bağlamda geliştirilmesi gerekmektedir.

Araştırma, Konya ili Selçuklu ilçesinde bulunan bir merkez devlet okulunda bulunan 46 ortaokul öğrencisinden elde edilen verilerle sinırlıdır. Benzer çalışmalar sosyo-kültürel ve ekonomik olarak farklılık gösteren farklı bölgelerde yer alan devlet ya da özel okullarda da yapılarak daha genel ve derinlemesine yorumlar yapılmasına olanak sağlanabilir.

Çalışma ortaokul Fen Bilimleri dersi 7. sınıf Maddenin İç Yapısına Yolculuk ünitesinin müfredatta yer alan kazanımlar ve zamansal programla sınırlıdır. Benzer çalışmalar farklı ünitelerin öğretiminde ve daha uzun zamanlı periyotlarda yapılarak farklı yorumlar elde edilebilir.

\section{KAYNAKLAR}

Alkan, C. (1998). Eğitim Teknolojisi (Genişletilmiş Beşinci Baskı). Ankara: Anı Yayıncılık.

Altınkaya, H. (1998). Türkiye’de Bilgisayar Destekli Eğitimin Gelişimi. Gazi Üniversitesi, Yayımlanmamış Yüksek Lisans Tezi, Ankara.

Altun, E., Uysal, E., ve Ünal, Ö. (1999). Bilgisayar destekli öğretimde yazılımların nitelik sorununa sistematik bir yaklaşım. Dokuz Eylül Üniversitesi Buca Eğitim Fakültesi Dergisi, 10, 217-230.

Arıkan, R. (2013). Araștırma yöntem ve teknikleri. Ankara: Nobel.

Baki, A. (2002). Öğrenen ve Öğretenler için Bilgisayar Destekli Matematik. Ankara: TÜBİTAK/Ceren Yayınları.

Bilgi, M., ve Şahin, M. (2012). Elementlerde Aktiflik Kavramının Öğretilmesinde Bilgisayar Destekli Öğretim Materyali Kullanılmasının Öğrenci Başarısı Üzerine Etkisi. Türk Fen Eğitimi Dergisi, 9(4), 146-166.

Büyüköztürk, Ş., Kılıç Çakmak, E., Akgün, Ö.E., Karadeniz, Ş., ve Demirel, F. (2011). Bilimsel araştırma yöntemleri. Ankara: Pegem.

Bybee, R. W., Carlson-Powell, J., \& Trowbridge, L. W. (2008). Teaching secondary school science: Strategies for developing scientific literacy. Columbus: Pearson/Merrill/Prentice Hall.

Campbell, D. T., \& Stanley, J. C. (1963). Experimental and quasi-experimental designs for research. Boston: Houghton Mifflin Company.

Cohen, J. C. (1988). Statistical power analysis for the behavioral sciences (2nd Ed.). Hillsdale, NJ: Lawrence Earlbaum Associates.

Çakır, H. (1999). Bilgisayar Destekli Eğitimde Grafik ve Animasyonlarının Kullanılması. Gazi Üniversitesi, Yayımlanmamı̧ Yüksek Lisans Tezi, Ankara.

Demirbaş, O. O., \& Demirkan, H. (2003). Focus on architectural design process through learning styles. Design Studies, 24(5), 437-456.

Demircioğlu, H., ve Geban, Ö. (1996). Fen Bilgisi eğitiminde bilgisayar destekli öğretim ve geleneksel problem çözme etkinliklerinin ders başarisi bakimindan karşilaş̧irilmasi. Hacettepe Üniversitesi Eğitim Fakültesi Dergisi, 12, 183-185.

Ekiz, D. (2009). Bilimsel araștırma yöntemleri: Yaklașım, yöntem ve teknikler. Ankara: Anı Yayıncılık.

Erdemir, N. (2011). The Effect of PowerPoint and Traditional Lectures on Students' Achievement in Physics. Journal of Turkish Science Education, 8(3), 176-189.

Güven, G., ve Sülün, Y. (2012). Bilgisayar Destekli Öğretimin 8.Sınıf Fen ve Teknoloji Dersindeki Akademik Başarıya ve Öğrencilerin Derse Karşı Tutumlarına Etkisi. Türk Fen Eğitimi Dergisi, 9(1), 68-79.

Hızal, A. (1989). Bilgisayar Ĕgitimi ve Bilgisayar Destekli Öğretime İlişskin Öğretmen Görüşlerinin Değerlendirilmesi. Eskişehir: Anadolu Üniversitesi Yayınları No: 338.

Kalaycı, Ş. (2010). SPSS Uygulamalı Çok Değişkenli İstatistik Teknikleri. Ankara: Asil.

Kartal, T. (2007). İlköğretim fen bilgisi öğretiminde aktif öğrenme yönteminin öğrencilerin başarllarına, tutumlarına ve hatırda tutmalarına etkisi. Selçuk Üniversitesi, Yayımlanmamış Yüksek Lisans Tezi, Konya.

Kartal, T., \& Afacan, Ö. (2017). Examining Turkish Pre-service Science Teachers’ Technological Pedagogical Content Knowledge (TPACK) Based on Demographic Variables. Journal of Turkish Science Education, DOI: 10.12973/tused.10187a. 
Koehler, M., \& Mishra, P. (2005). What happens when teachers design educational technology? The development of technological pedagogical content knowledge. Journal of Educational Computing Research, 32(2), 131152.

Liao, Y. C. (2007). Effects of computer-assisted instruction on students'achievement in Taiwan: A meta-analysis. Computers \& Education, 48(2), 216-233.

Morse, R. H. (1991). Computer uses in secondary science education. ERIC Clearinghouse on Information Resources, Syracuse University, School of Education, School of Information Studies.

Namlu, A. G. (1999). Bilgisayar Destekli İşbirliğine Dayalı Öğrenme. Eskişehir: Anadolu Üniversitesi Yayınları No: 1145.

Özdamar, K. (2004). Paket programlar ile istatistiksel veri analizi. Eskişehir: Kaan Kitabevi.

Özmen, H., ve Kolomuç, A. (2004). Bilgisayarlı Öğretimin Çözeltiler Konusundaki Öğrenci Başarısına Etkisi. Kastamonu Eğitim Dergisi, 12(1), 57-68.

Plano Clark, V. L., \& Creswell, J. W. (2015). Understanding research: A consumer's guide. Upper Saddle River, NJ: Pearson Education.

L. Rogers and H. Finlayson. (2002). Integrating ICT in the teaching of science in secondary schools, International Conference on Computers in Education Proceedings, (1), pp. 685-686.

Rosenthal, R., \& Rosnow, R. L. (1991). Essentials of behavioral research: Methods and data analysis (2nd Ed.). New York: McGraw Hill.

Sheingold, K., Heller, J. I., \& Paulukonis, S. T. (1995). Actively seeking evidence: Teacher change through assessment development (Rep. No. MS 94-04). Princeton, NJ: Educational Testing Service, Center for Performance Assessment.

Şahin, T. Y., ve Yıldırım, S. (1999). Öğretim Teknolojileri ve Materyal Geliştirme. Ankara: Anı Yayıncılık.

Şahinkayası, Y., ve Şahinkayası, H. (2004, Temmuz). Okullar Iç̧in Öğretim Teknolojisi Planı (ÖTP) ve Öğeleri. Bildiri, XIII. Ulusal Eğitim Bilimleri Kurultayı, Malatya.

Şeker, R., Yener, D., ve Özkaya, A. (2002). Konya Merkez İlköğretim Okullarında Fen Bilgisi Derslerinin Verilmesinde Teknolojik Olanaklardan Yararlanma Düzeylerini Belirlemeye Yönelik Bir Çalışma. 16- 18 Eylül ODTÜ Kültür ve Kongre Merkezi, Ankara.

Tekin, H. (2003). Ĕgitimde Ölçme ve Değerlendirme. Ankara: Yargı yayınları.

Topsakal, S. (2006). Fen öğretimi. (Geliştirilmiş 2. Baskı). Ankara: Nobel Yayın Dağıtım.

Uçar, M. (1999). İlköğretimde ders araç-gereçleri kullanımı konusunda öğretmen görüşlerinin değerlendirilmesi. Afyon Kocatepe Üniversitesi Sosyal Bilimler Dergisi, 1(3), 195-207.

Uşun, S. (2000). Dünya da ve Türkiye’de Bilgisayar Destekli Öğretim. Ankara: Pegem A Yayınevi.

Whitman, D. S., Van Rooy, D. L., Viswesvaran, C., \& Alonso A. (2008). The susceptibility of a mixed model measure of emotional intelligence to faking: A Solomon four-group design. Psychology Science Quarterly, 50(1), 44-63. 